\title{
Establishment of Bukit Kayu Hitam as a Special Border Economic Zone (SBEZ): Global lessons
}

\author{
Muhammad Fadhlullah Najimudin ${ }^{1}$, Nuarrual Hilal Md Dahlan², Mohd Zakhiri Md. Nor ${ }^{3}$ \\ 1 Department of Urban and Regional Planning, \\ Faculty of Built Environment \& Surveying, Universiti Teknologi Malaysia, \\ 2 Professor of Law, School of Law, College of Law, \\ Government and International Studies, Universiti Utara Malaysia \\ 3 Senior Lecturer, School of Law, College of Law, \\ Government and International Studies, Universiti Utara Malaysia
}

fadhlullah.najimudin@gmail.com, nuarrualhilal@uum.edu.my, zakhiri@uum.edu.my

Tel: +6010-401 8801

\begin{abstract}
Special Economic Zones (SEZs) is one of the known mechanisms to attract Foreign Direct Investment (FDI). Nevertheless, there was a global mix reaction towards its successful implementation with a few operational failures, especially in the area of its legal framework. Therefore, this paper aim is to explore the success and failure experience to be a reference for the development of Special Border Economic Zone at Bukit Kayu Hitam using qualitative textual analysis. It finds that two significant issues in SEZs; regulatory/ legal framework, and development spill-over.
\end{abstract}

Keywords: Special Economic Zones; Land Use Planning Law; Policy Implementation; Bukit Kayu Hitam

eISSN: 2398-4287@ 2020. The Authors. Published for AMER ABRA cE-Bs by e-International Publishing House, Ltd., UK. This is an open access article under the CC BYNC-ND license (http://creativecommons.org/licenses/by-nc-nd/4.0/). Peer-review under responsibility of AMER (Association of Malaysian Environment-Behaviour Researchers), ABRA (Association of Behavioural Researchers on Asians) and cE-Bs (Centre for Environment-Behaviour Studies), Faculty of Architecture, Planning \& Surveying, Universiti Teknologi MARA, Malaysia. DOI: https://doi.org/10.21834/ebpj.v5i14.2270

\subsection{Introduction}

Economic development, without doubt, is the backbone of a particular country. The economic growth will be the yardstick in determining the success of a nation. For a developing or less developed country, the involvement of foreign investors is crucial to ensure that their economy can become more potent (Dorozyński et al., 2016). Foreign Direct Investment (FDI) is one of the potential tools to increase economic growth. Johnson (2006) discussed that FDI does not only increase the economic growth of the host country, but the country also benefits from technology spill-over from the FDI that operate in their country. Most of the countries' policymakers have innovatively created various incentives to attract investors (e.g., tax incentives, export processing zones, economic zone, tariffs, subsidies). The implementation of FDI is assumed to create a remarkable impact on local economic development (Dorozyński et al., 2016). Thus, to spur the economic growth of a country, policymakers should not only emphasise the local economy or investment flow only, but they should also invite more FDIs to the host country.

One of the critical policy mechanisms that have been implemented in most countries to attract investment, especially for industrial development, is Special Economic Zones (SEZs). SEZs can be generally defined as demarcated geographic areas contained within a country's national boundaries, where the rules of business are different from those that prevail in the national territory (Farole \& Akinci, 2011). These differential rules principally deal with investment conditions, international trade and customs, taxation, as well as the regulatory environment which intended to be more politically liberal and administratively competent than other areas of that particular national territory (Farole \& Moberg, 2017). Up to this point, there was a globally mixed reaction with major succeeding projects in Asian

eISSN: 2398-42870 2020. The Authors. Published for AMER ABRA cE-Bs by e-International Publishing House, Ltd., UK. This is an open access article under the CC BYNC-ND license (http://creativecommons.org/licenses/by-nc-nd/4.0/). Peer-review under responsibility of AMER (Association of Malaysian Environment-Behaviour Researchers), ABRA (Association of Behavioural Researchers on Asians) and cE-Bs (Centre for Environment-Behaviour Studies), Faculty of Architecture, Planning \& Surveying, Universiti Teknologi MARA, Malaysia.

DOI: https://doi.org/10.21834/ebpj.v5i14.2270 
and Latin America but operational difficulties in Africa. China's Shenzhen is often cited as one of the SEZs best practices in the world, and other SEZs have also followed a similar concept. Regardless of its failure in certain countries, World Investment Report 2019 reported that more than 1,000 SEZs have been established in the last five years around the globe and expecting at least 500 more to be in the circle in a few coming years (United Nations, 2019). Therefore, understanding the issues and problems of SEZs' establishment is essential to ensure that the future development of SEZs will enable to encounter any shortcoming of the development. This conceptual paper will be directed to identify and analyse the risk and challenges in the perspective of land use planning law that will be incorporated together in ensuring that BKH will become a prime economic border zone in the northern part of Peninsular Malaysia.

\subsection{Special Economic Zones}

Conceptually, SEZs can be generally defined as an instrument to promote the increase of trade through reducing the customs oversight and offers various taxation schemes. It adopts a different framework compared to other areas in the country to accommodate that specialised industry, diverse working environment as well as having excellent infrastructure. The term "special economic zones" (SEZs) have different interpretations and types such as free-trade zones (FTZ), export-processing zones (EPZ), industrial parks, economic and technology-development zones, high-tech zones, science and technology parks, free ports, enterprise zones, and many others (Farole \& Moberg, 2017; Zhihua Zeng, 2019). Table 1 summarises brief definitions of the various types of SEZs around the world.

Table 1. Definition of SEZs

\begin{tabular}{|c|c|}
\hline Name & Definition \\
\hline Free Trade Zones (FTZ) & $\begin{array}{l}\text { FTZ (also known as commercial free-zones) is duty-free areas. It includes warehousing, } \\
\text { warehouse and logistics infrastructure to shipping, transport and re-export activities, which are } \\
\text { also classified as commercial-free areas. }\end{array}$ \\
\hline Export Processing Zones (EPZ) & $\begin{array}{l}\text { EPZs is an industrial area that mainly for the international market. It offers a free-trade condition } \\
\text { with a flexible regulatory environment. Typically, two types of EPZs exist: one is a comprehensive } \\
\text { type, available to all industries; the other is a specialised type, access to particular specialised } \\
\text { products/sectors. }\end{array}$ \\
\hline Comprehensive Special Economic Zones & $\begin{array}{l}\text { Comprehensive SEZs are large size zones that have mix-used development such as services, } \\
\text { industrial, and other operations of urban facilities. Examples of these zones that cover almost the } \\
\text { whole territory are Shenzhen (city) and Hainan (Province) in China. }\end{array}$ \\
\hline Bonded Area & $\begin{array}{l}\text { Bonded Areas/Warehouse are particular buildings or other protected areas where goods may be } \\
\text { processed, handled or produced without payment of ordinary duties. To some extent, a "bonded } \\
\text { area" is identical to a "free trade zone" or "free port." The key difference, though, is that a "bonded } \\
\text { area" is subject to customs laws and regulations, while a "free trade zone" is excluded from these } \\
\text { rules. }\end{array}$ \\
\hline Specialized Zones & $\begin{array}{l}\text { Specialized zone commonly is related to science and technology park, logistics and warehouse } \\
\text { park, petrochemical zone, tourist and recreational zones, gambling zones and many others. }\end{array}$ \\
\hline
\end{tabular}
(Source: Zhihua Zeng, 2019)

\subsection{Special Economic Zone Best Practice: Shenzhen}

One of the best practices of SEZ in the world is Shenzhen, China. Shenzhen is located in the South China Sea, with a total area of $2,000 \mathrm{~km} 2$, which is equivalent to approximately 500,000 acres. Shenzhen can be accessed through various types of transportation which include its International Airport and nine ports across its $230 \mathrm{~km}$ beach line, either for passenger or cargo ship. It can also be reached by using a train which connects to other main big cities, including Beijing and Guangzhou. Since its establishment in the 1980s, Shenzhen has grown from 30,000 inhabitants to approximately 13 million residents at the end of 2018 (Janjua et al., 2018). It has become the leading global technology hub in China. The Chinese government has decided to develop and grow the area as part of its SEZs in 1980 because of its location advantage that neighbouring and border with Hong Kong (Crane et al., 2018).

Shenzhen has started to become a high technologies industries hub in the mid-1990s. It is currently a home for several prestigious tech firms (Herlevi, 2016) such as the second top mobile phone manufacturer, Huawei, top drone maker DJI as well as ZTE, China telecommunication company. That is one of the main reasons Shenzhen is well-known as a Silicon Valley in China. Besides being the dominant player in the high technology industry, Shenzhen has its independent stock exchange market that operates in Mainland China. The stock market is listed as the 8th largest stock exchange in the world (World Federation of Exchange, 2018). Furthermore, these economic centres them to leverage the financial investment from Hong Kong that has contributed to the success of Shenzhen today.

Despite being one of the largest stock exchanges in the world, the government has come out with proper planning on SEZ itself. To ensure that the development of SEZs can run smoothly, Shenzen Municipal Council has formulated the Master Plan of Shenzhen Special Economic Zone in the year 1982. Later, in 1986, they came out with the Shenzhen SEZ Master Plan (1986-2000). This plan adopted cluster and point-axis spatial layout to control urban development within the SEZ. However, a lack of systematic planning of the development outside the SEZs has resulted in disordered land use and development. To further control urban sprawl, the Shenzhen municipal government formulated the Shenzhen City Master Plan (1996-2010) (Ng, 2017). This plan was more comprehensive urban planning that attempted to coordinate and manage city development. The latest masterplan, Shenzhen 2030, aims to emphasise the connectivity within the region, together with more large green infrastructure and ecological spaces towards sustainable development goals. An essential part of urban planning, the layout of rail transportation plays a vital guiding role in urban development and redevelopment.

Besides, the practice of the three-tier government level, i.e., Central; Provincial; and Local has greatly influenced the process of preparing and implementing relevant policy. The central government of China gave the provincial and local authority a level of autonomy 
which allows them a space to manoeuvre their execution part. Decentralisation of the central government has indirectly extended power given to the Guangdong provincial government and the exclusive zone government in terms of the foreign economic activities, business management, labour, wages and urban planning and others (Wu et al., 2017). The local regulator can formulate their policies and guidelines which can expedite any process that might be delayed if the central government is involved. In his book, Ge (1999) comes out with a term or model called "smaller government and larger society" approach. This approach enables Shenzhen to sustain itself by developing the regulation for the investment in their region. Bureaucratic issues, time-consuming, tax-exemption, recruitment processes are among the significant attribute that will be considered by investors when they plan to set their business in the host country (Johnson, 2006; Ng, 2017). Thus, decentralisation by the central government, which conferred the autonomy to Shenzhen local authority has ease and expedites the process mainly applied to investors.

\subsection{Methodology}

\subsection{Study Area}

Bukit Kayu Hitam, a border town between Malaysia and Thailand, aims to become one of North Peninsular's newly industrialised economic zones. It is located in Rapid infrastructure growth has triggered economic development and social growth in this region. The opportunities for economic properties in Bukit Kayu Hitam, including a wide range of commercial, residential, industrial and public areas, are gaining expected to hit the spot once the development is in place. The Malaysian 2019 Budget was planned and approved to turn Bukit Kayu Hitam into an exclusive duty-free zone. This is primarily affected by the SBEZ's geographic position and the main entrance gateway to the northern area.

As part of NCER Development Blueprint 2016-2025, Bukit Kayu Hitam is the only border town in Malaysia located on the Asian Highway Network, which links Singapore and Thailand. It will be part of the significant area that will be developed in this blueprint. Furthermore, Kedah Science and Technology Park (KSTP), located in Bukit Kayu Hitam territory, will be developed as Global Research Center and Modern Industrial Park, which later will be a complement to each other (NCER, 2017). KSTP, which worth RM5 billion megadevelopment will be a part of the SBEZ that has been proposed as one of the developments and economic catalysts in Kedah State Structure Plan 2035 (RSN Kedah 2035). This economic zone will consist of factories, shopping complexes, housing, hotels, recreation parks, education centres and new Immigration, Customs, Quarantine and Security (ICQS).

\subsection{Data Analysis}

The purpose of this research is to explore the issues and problems in the development of SEZs around the globe through a qualitative textual analysis approach from primary and secondary data to explore and study the issues and problems on the development of SEZs around the world via land use planning law. It involved a literature review from the articles, books, journals, and legal cases related to SEZs and land use planning. The stages are as follows:

\section{Stage One}

Identification on the features of SEZs (1) Category of SEZs, i.e., FTZ, EPZ, Comprehensive SEZs and other, (2) Incentives offered, i.e., subsidies, tax exemption, employment incentives and others. The details in regards to the definition, theories and attributes were further analysed and explored to get a better understanding of SEZs as done in Section 2.0.

\section{Stage Two}

Identification of issues, problems and challenges in the establishment of SEZs around the globe. The authors do not pretend to discuss further the success of SEZs but wish to contribute to the debate and study on issues that arise from the development of SEZs. Thus, findings and critical analysis from the earlier research were reviewed and will be used for this study. Hence, a new, more integral approach to today's SEZs will be discussed as an essential source to add value for the formulation and implementation of the legal framework concerning the SEZs.

\subsection{Study Limitation}

This research was only confined to the legal framework from the perspective of physical planning. Economic and social aspects were not being covered in which it is among the vital factors that need to be integrated for the successful establishment of SBEZ at Bukit Kayu Hitam.

\subsection{Results and Discussions: Issues, Problems and Challenges}

Despite having various initiatives and proposals on the development of SEZ in Bukit Kayu Hitam, however, there is a need for thorough strategic planning to be undertaken before the scheme can be executed. Easy policies and guidelines, which are more practical need to be established in the execution of SBEZ at Bukit Kayu Hitam. Furthermore, there several critical success factors that can lead to successful SEZs, i.e.: (1)macroeconomic and location advantages of a country; (2) stability and consistency of the government; (3) support on the industrial investment; (4) cost efficiency; (5) ability to offer best human resources services; (6) high-quality infrastructure, (7) management and service (8) law, regulations and government policy (Pakdeenurit et al., 2017; Wahyuni et al., 2013). Thus, looking 
into the frameworks discussed in previous research, it is a serious challenge to incorporate all these factors to ensure that Bukit Kayu Hitam will become the prime economic border zone in the northern part of the Peninsular of Malaysia.

Nevertheless, from authors' knowledge and finding, there is a shortage of legal writing that discussing the legal frameworks and land use planning law that governs the development of SEZs and SBEZs in Malaysia despite having the Economic Corridor since 2006. Upon analysing the legal issues in the development of the SBEZs and SEZs in other countries, the authors will focus on two main issues as follows:

\subsection{The problematic legal and regulatory framework governing the SEZs and SBEZs}

The SEZs concept, without a doubt, has been verified by most of the countries to boost their economic growth. However, behind all these successes lies many issues that can affect the execution of SBEZ in the long run. The lack of regulation or the policy implementation for SEZ can somehow create much confusion and affect the investors' confidence towards the host country. Issues and problem such as strategic planning of SEZs, bureaucratic redundancy in registration, the unattractive package offered, customs clearance, taxation disadvantages, foreign exchange and economic instability, long-process for development, immigration issues with foreign workers and many other items have indirectly constraint the overall SEZ environment and deterred the prospective investor. The problems have been documented as relevant to SEZs worldwide, such as China, Africa, the United States, and Australia (Lord \& Tangtrongita, 2014; Zhihua Zeng, 2019).

Hence, the empirical analysis of the laws governing SBEZ's performance in Bukit Kayu Hitam is essential and useful for a variety of reasons mainly to understand the texture and scope of legal issues related to land use planning. The diversity of legal obligations, expressed in international treaties and domestic/national legislation, shows the value of land use policy for the growth of Bukit Kayu Hitam and strategic paradigms and strategies for the determination of state and local law enforcement. Therefore, this research is vital in understanding and evaluating critical legal problems that may hinder and affect the creation and execution of SBEZ projects and which may complicate supporting factors.

Furthermore, there appears a need to investigate the importance of the local plan itself mainly on the primary land use, i.e.: (1) housing; (2) commercial; (3) industrial;(4) open spaces; and (5) transportation sector in ensuring a well-planned development of SBEZ in Bukit Kayu Hitam. In current practice, any changes in land use zoning can be carried out by the local authority. However, the most crucial part is on the gazettement of the changes which might take a longer time (Md Dahlan et al., 2019; Yakob et al., 2012). Besides, Pasir Gudang Municipal Council and Kulim Hi-Tech Industrial Park Local Authority which applying the concept of "Exclusive Local Authority" has the potential to be further explored. Both of these local authorities were established under Section (3) and (7), Local Government Act 1976 (Act 171), to govern the SEZ for both areas. The new land-use planning legal framework should be one of the mechanisms in promoting and stimulating the economic development of the SBEZ in Bukit Hitam. The recommendation will lead to a comprehensive legal framework for the land use planning as well as the development of land and infrastructure in the SBEZ region. A precise formulation and implementation of these legal frameworks can guide SBEZ in Bukit Kayu Hitam to encounter the issues and challenges (Pakdeenurit et al., 2017; Zhihua Zeng, 2019). It is important to note that sustainable development needs to harmonise its implementation activities and environmental protection (Masum et al., 2017).

\subsection{Development spill-over side-effect problems and issues}

The development of SEZ and since the year 1970' has offered many lessons to be learned to the newly established economic zone like Bukit Kayu Hitam. Various information on its success, issues and problems should be taken into consideration for a new development of the economic zone. One of the significant problems that arise is the spill-over effect of the development of SEZs. SEZs have created much ink had been spilt on the 'land wars' which indirectly increased the demand and create land speculation surrounding the SEZs (Levien, 2012). Besides, in China, the spill-over effect due to rapid urbanisation in SEZs also created urban and regional development disparities with another region if it is not fully integrated (Crane et al., 2018). Thus, this rapid urbanisation will indirectly give an implication on the land use management either within the SEZs itself or their surrounding area.

Rapid urbanisation can create a land-use transition by the expansion of the economic zone itself. This expansion, without a doubt, brought good economic growth but can also create a series of environmental issues. Thus, the ecological effect of the land-use transition, in most cases, tends to harm the environment (Qu \& Long, 2018). In the early year 2019, Malaysian was shocked by water pollution caused by illegal chemical waste dumping at Kim-Kim River in Pasir Gudang (Ibrahim et al., 2019). Pasir Gudang is part of development in Iskandar Malaysia, one of the thriving Economic Corridor in Malaysia. The lacking-of thorough appraisal especially on environmental aspects prior to development consent issued by the relevant regulators has significantly paved the way to the increasing environmental issues (Md Dahlan, 2019; Yakob et al., 2016). Yap et al., (2019) also supported this, which stated that the massive pollution that involves health implications would trigger immediate actions from the government compared to regular complaints or report from the public. This problem was also happening in Langkawi, whereby the development to cater to the area itself as a tourism destination has indirectly affected the natural environment of that island (Samat, 2010; Thompson et al., 2018). Thus, thorough and meticulous enforcement need to be carried out by the related government agencies to achieve comprehensive development within the proposed SEZs (Md. Nor, 2017; Mohiuddin et al., 2014; Wu et al., 2017).

\subsection{Conclusion and recommendation for future research}

Inefficient and improper planning can lead to haphazard development of emerging cities and loss of enormous resources. In the long run, any development that creates problems generated by them such as congestion, pollution, inefficiency and resource depletion. As 
"Prevention is better than cure," this research writing helps to identify and analyse the planning policy gaps and implementation challenges of previous and current SEZ around the globe. In addition to that, this research writing will give input and reference to the government in promoting SBEZ's development as spelt out in Kubang Pasu Local Plan, Kedah State Structure Plan as NCER Blueprint 2.0 (2016-2025). Further, this research writing outcome will help the policymakers and the implementation agencies either in the State Government or Federal Government to achieve the objectives as provided in the NCER Blueprint 2.0 and the 11th Malaysia Plan (20162020). By and large, the outcomes of this research writing will help the government to achieve the objectives as set out in the Shared Prosperity Vision 2030, National Key Economic Areas (NKEA), Government Transformation Programme (GTP), Economic Transformation Programme (ETP), IMT-GT Vision 2026, IMT-GT Implementation Blueprint 2017-2021 as well as Sustainable Development Goal and New Urban Agenda by United Nation.

Drawing on the recorded low success rate of SEZ growth around the globe, the absence of empiric studies on the legal framework, with the lack of a fundamental valid framework for SEZ, it is recommended that further research will look into the impact of land use planning mainly to control the development of SEZ itself. The overlapping, insufficient policies and regulations need to be identified uniquely in terms of the functions, jurisdiction as well as liabilities of land use planning framework in governing the development of SBEZ in Bukit Kayu Hitam. An exploratory study should be carried out at the outset of this process to increase knowledge of land use planning in the context of SEZ. These studies will require the identification of critical success drivers for SEZ with proper land use planning. Thus, it is expected that future research will further come-out with the recommendation of a comprehensive and relevant legal framework governing the smooth growth of the SEZ in Bukit Kayu Hitam. The formulation and establishment of an integrated and coherent framework to ensure that SBEZ will be able to encounter issues and challenges that will be faced by the SBEZ soon (Marzukhi et al., 2012; Pakdeenurit et al., 2017).

\section{Acknowledgements}

The author would like to thank Universiti Teknologi Malaysia (UTM) for the funding of this research through Skim Latihan Akademik Muda (SLAM) scholarship.

\section{References}

Crane, B., Albrecht, C., Duffin, K. M., \& Albrecht, C. (2018). China's special economic zones: An analysis of policy to reduce regional disparities. Regional Studies, Regional Science, 5(1), 98-107. https://doi.org/10.1080/21681376.2018.1430612

Dorozyński, T., Świerkocki, J., \& Urbaniak, W. (2016). The FDI inflow to special economic zones in Poland. Contemporary Studies in Economic and Financial Analysis, 98, 135-159. https://doi.org/10.1108/S1569-375920160000098009

Farole, T., \& Akinci, G. (2011). Special Economic Zones. In Special Economic Zones. https://doi.org/10.1596/978-0-8213-8763-4

Farole, T., \& Moberg, L. (2017). Special Economic Zones in Africa: Comparing Performance and Learning from Global Experience. In The International Bank for Reconstruction and Development / The World Bank. The International Bank for Reconstruction and Development / The World Bank.

Ge, W. (1999). Special Economic Zones and the Economic Transition in China. World Scientific.

Herlevi, A. A. (2016). What's so Special about Special Economic Zones? China's National and Provincial-Level Development Zones. ISA Asia-Pacific Conference 2016.

Ibrahim, I., Hua, K. P., \& Omoola, S. (2019). Corporate Environmental Responsibility in Malaysia and India: A Preliminary Analysis. Environment-Behaviour Proceedings Journal, 4(11), 195. https://doi.org/10.21834/e-bpj.v4i11.1662

Janjua, S., Khan, A., \& Asif, N. (2018). Sustainable Urban Development and SEZs Consideration for China Pakistan Economic Corridor. 014, 1-17.

Johnson, A. (2006). The Effects of FDI Inflows on Host Country Economic Growth. Centre of Excellence for Science and Innovation Studies, 58, 1-57.

Levien, M. (2012). The land question: Special economic zones and the political economy of dispossession in India. Journal of Peasant Studies, 39(3-4), 933-969.

Lord, M., \& Tangtrongita, P. (2014). Special Border Economic Zone ( SBEZ ) in the Indonesia-Malaysia-Thailand Growth Triangle ( IMT-GT ). May.

Marzukhi, M. A., Omar, D., \& Hoon Leh, O. L. (2012). Re-appraising the Framework of Planning and Land Law as an Instrument for Sustainable Land Development in Malaysia. Procedia - Social and Behavioral Sciences, 68, 767-774.

Masum, A., Nafees, S. M., Md. Nor, M. Z., \& Ahmed, K. H. W. @ M. H. (2017). The Right to Development Versus Envirinmental Protection With Special Reverence to Federal Constitution. Advanced Science Letters, 23(9), 9072-9075.

Md. Nor, M. Z. (2017). The Joint Roles of Executive Govenmental Functionaries in Enhancing the Islamic Economy System,. Advanced Science Letters., 23.

Md Dahlan, N. H. (2019). Planning case law and legal issues in abandoned housing projects in Malaysia. 4th International Conference on Education, Islamic Studies and Social Science Research and International Conference on Science and Technology (ICEISR \& ICOST) 2019-Research Education: Opportunities and Challenges for Fourth Industrial Revolution.

Md Dahlan, N. H., Mohamed Nafees, S. M., \& Ahmad, M. H. (2019). A Planning Law Perspective On Abandoned Housing Projects In Malaysia. In Selected Legal Issues in Indonesia and Malaysia (pp. 98-117). UNISSULA PRESS, Universitas Islam Sultan Agung, Semarang, Indonesia. 
Mohiuddin, M., Regnière, M. H., Su, A., \& Su, Z. (2014). The special economic zone as a locomotive for green development in China. Asian Social Science, 10(18), 109121. https://doi.org/10.5539/ass.v10n18p109

NCER. (2017). Transforming the Socioeconomic Landscape of Ncer.

Ng, M. K. (2017). Governing green urbanism: The case of Shenzhen, China. Journal of Urban Affairs, 41(1), 64-82. https://doi.org/10.1080/07352166.2016.1271623

Pakdeenurit, P., Suthikarnnarunai, N., \& Rattanawong, W. (2017). Location and key success factors of special economic zone in Thailand. Marketing and Branding Research, 4(2), 169-178. https://doi.org/10.33844/mbr.2017.60355

Qu, Y., \& Long, H. (2018). The economic and environmental effects of land use transitions under rapid urbanisation and the implications for land use management. Habitat International, 82(April), 113-121. https://doi.org/10.1016/j.habitatint.2018.10.009

Samat, N. (2010). Assessing land use land cover changes in Langkawi island: Towards sustainable urban living. Malaysian Journal of Environmental Management, 11(1), 48-57.

Thompson, B. S., Gillen, J., \& Friess, D. A. (2018). Challenging the principles of ecotourism: insights from entrepreneurs on environmental and economic sustainability in Langkawi, Malaysia. Journal of Sustainable Tourism, 26(2), 257-276. https://doi.org/10.1080/09669582.2017.1343338

United Nations. (2019). World Investment Report 2019 (United Nations Conference on Trade and Development) (Issue June 2019).

Wahyuni, S., Astuti, E. S., \& Utari, K. M. (2013). Critical Outlook At Special Economic Zone in Asia: a Comparison Between Indonesia, Malaysia, Thailand and China. Journal of Indonesian Economy and Business, 28(3), 336-346. https://doi.org/10.22146/jieb.6218

World Federation of Exchange. (2018). List of Stock Market Exchange. https://www.world-exchanges.org/

Wu, C., Wei, Y. D., Huang, X., \& Chen, B. (2017). Economic transition, spatial development and urban land use efficiency in the Yangtze River Delta, China. Habitat International, 63, 67-78. https://doi.org/10.1016/j.habitatint.2017.03.012

Yakob, H., Yusof, F., \& Hamdan, H. (2012). Land use Regulations Towards a Sustainable Urban Housing: Klang Valley Conurbation. Procedia - Social and Behavioral Sciences, 68(December), 578-589. https://doi.org/10.1016/j.sbspro.2012.12.250

Yakob, H., Yusof, F., \& Hamdan, H. (2016). Strategies to Improve the Implementation of Planning Mechanisms for Urban Housing Development in Selangor. EnvironmentBehaviour Proceedings Journal, 1(4), 145. https://doi.org/10.21834/e-bpj.v1i4.380

Yap, C. K., Peng, S. H. T., \& Leow, C. S. (2019). Contamination in Pasir Gudang Area, Peninsular Malaysia: What can we learn from Kim Kim River chemical waste contamination? Journal of Humanities and Education Development, 1(2), 82-87. https://doi.org/10.22161/jhed.1.2.4

Zhihua Zeng, D. (2019). Special Economic Zones: Lessons from the Global Experience. In PEDL Synthesis Paper Series 1: Vol. volume 9 (No. 1; 1, Issue 3). 